\title{
Analysis of the Active and Passive Fire Protection Systems in the Government Building, Depok City, Indonesia
}

\section{Zulkifli Djunaidi', NAA Tuah'2,3, and Ghina Rafifa ${ }^{1}$}

${ }^{1}$ Occupational Health and Safety Department, Faculty of Public Health, Universitas Indonesia, Jl. Margonda Raya, Beji, Pondok Cina, Kota Depok, Jawa Barat 16424, Indonesia

${ }^{2}$ PAPRSB Institute of Health Sciences, Universiti Brunei Darussalam, Jalan Tungku Link, Gadong BE1410, Brunei Darussalam

3Primary Care and Public Health Department, School of Public Health, Imperial College London, Kensington, London SW7 2AZ, United Kingdom

\section{Abstract}

In many countries, fires in buildings have resulted in loss of many lives, damaged properties and financial losses. In Indonesia, there has been increasing reported cases

Corresponding Author: Zulkifli Djunaidi zul@ui.ac.id

Received: 15 May 2018 Accepted: 3 June 2018 Published: 19 June 2018

Publishing services provided by Knowledge $\mathrm{E}$

(c) Zulkifli Djunaidi et al. This article is distributed under the terms of the Creative Commons Attribution License, which permits unrestricted use and redistribution provided that the original author and source are credited.

Selection and Peer-review under the responsibility of the ICOHS 2017 Conference Committee. of fire occurring in public buildings over the years. This study aimed to assess the risks of fire and fire protection systems in government office buildings in Depok, Indonesia. A descriptive study was conducted using triangulation approaches on government buildings in Depok from March to April 2016. Primary and secondary data was collected using observation, unstructured interview of key informants and documentation review. Descriptive and comparative data analyses were conducted in the study. The key problems identified in the fire protections systems in the building were heat detector installed near the air conditioner, damaged to the alarm circuits, sprinklers mounted at a distance exceeding the applicable regulations, lack of complete hydrants, and a lack of fireproof doors and windows. The gap between standard/regulation and the condition of fire protection systems in the building are based on a lack of knowledge about the essence of the building management system and standard fire protection. There are minimal active and passive fire protection systems in office buildings, and few components are not adequately practiced in accordance with international and local standards and regulations. For safe system of work, the entire fire protection system need to be tested periodically so that the system would work well in case of an emergency. It is important to conduct regular inspections and maintenance of the fire protection systems specifically in office buildings.

Keywords: active fire protection system, fire, National Fire Protection Association, passive fire protection system

\section{G OPEN ACCESS}




\section{Introduction}

Fires can occur anywhere at any time and have serious consequences including loss of many lives, damaged properties and financial losses in many countries. The United States has reported 1.298 million fire cases in 2014 that resulted with 3,275 deaths, 15,775 injuries, and property damaged costs amounted of $\$ 11.6$ billion [1]. Furthermore, there were 494,000 cases of building fire out of those 1.298 million of cases reported. Each year 3,340 cases of fire reported occurring in office buildings from 2007 to 2011 [1]. Meanwhile, Indonesia has estimated of 20,000 to 100,000 cases of fire affecting public buildings in 2015 [2]. Jakarta alone has reported 180 cases of fire in office buildings [3]. In Depok District, the reported cases of fire has increased from 2007 to 2015. Furthermore, 226 cases of fire were reported with financial costs approximately 8.945 billions rupiah in 2015 [4].

It is important to prevent fires in office buildings because failure to control fires may not only mean workforces are breaking the law with the associated possible fines and other enforcement action. Also, workforce could suffer high financial loss (from damaged equipment and buildings) and serious injury, perhaps death, should a fire start. The risks of fire in an office building are subjected to five main hazards including: direct burning due to discard of smoking materials (as source of ignition of flammable objects); arching due to defective wiring and poor periodic servicing of electrical equipment (such as computers, copiers, printers, and fax machines); radiation fire due to overheat of portable equipment not switch off (e.g., kitchen electronic utensils); conduction fire due to poor house-keeping of flammable materials (such papers and plastics); and hot surface or friction due to repair activities such as welding that may cause a fire [5].

There has been increasing reported cases of fire occurring in public buildings over the years in Indonesia and Jakarta. The failure to control fire risks can result in heavy loss to the organization in terms of injury to the workforce, financial loss due to property and equipment damage and legal consequences. Therefore, the study aimed to assess the risks of fire and fire protection systems in government office buildings in Depok in Indonesia. 


\section{Methods}

\subsection{Design and subjects}

It is a descriptive study conducted from March to April in 2016 in a government building in Depok and involving three participants (Technician of the building, Inspector of Fire Department and General Affair). Depok is experiencing rapid development and is located in the West Java. West Java is one of the provinces with the highest population density after Jakarta in Indonesia.

\subsection{Data collection}

Primary and secondary data was collected using triangulation methods consisting of observation, unstructured interview of key informants and documentation review. The observation was carried out based on a checklist modified from National Fire Protection Association standards for active fire protection systems (such as heat and smoke detectors, fire alarms, automatic sprinklers, standpipe systems, and portable fire extinguishers) and passive fire protection systems (e.g., building construction, fire-resistant materials, fire doors and windows, compartmentalization, and interior finishes) [6]. A pre-tested and modified guideline based on National Fire Protection Association standards were used during the interviews. The documents reviewed were layout plan of the buildings, equipment specifications, and other supporting guidelines available.

\subsection{Data analysis}

Descriptive and comparative data analyses were conducted in the study. The data gathered through assessing the actual conditions was compared to the applicable standards, such as the NFPA 1: Fire Code [7], NFPA 10: Standard for Portable Fire Extinguisher, [8] NFPA 13: Standard for the Installation of Sprinkler Systems [9], NFPA 14: Standard for the Installation of Standpipe and Hose Systems [10], NFPA 72: National Fire Alarm and Signaling Code [11], NFPA 101: Life Safety Code [12], NFPA 220: Standard on Types of Building Construction [13], NFPA 5000: Building Construction and Safety Code [14], and local regulations such as Regulation of the Minister of Public Works No. 26/PRT/M/2008 on Technical Requirements for Fire Protection System in Buildings and the Environment [15] and Regulation of the Mayor of Depok No. 14 Year 2012 on Technical Requirements for Fire Protection System in Buildings and Environment [16]. 
These standards and regulations address the technical requirements for fire protection systems in buildings and the environment.

\section{Results}

The study found that the existing active and passive fire protection systems in the building conform to the standards and regulations. There were some areas not practiced in accordance with the NFPA standards and other Regulations.

\subsection{Active fire protection system}

As shown in Table 1, few of the fire detectors are installed close to (approximately 40-50 cm) air conditioning vent of the Government Building and their location are recorded. All detectors have been tested and inspected by competent inspectors at least once a year. Fire alarms and strobe light notifications are installed at the height of $1.4 \mathrm{~m}$ above the floor and mounted parallel or in the same place of manual call point (TPM), which is above the hydrant box. The frequency of alarm testing is in accordance with NFPA 72 and Regulation of the Ministry of Public Works No. 26/PRT/M/2008. A wet-pipe type of sprinkler installation is used in the building, in accordance with Regulation of the Ministry of Public Works No. 26/PRT/M/2008 and Regulation of the Mayor of Depok No. 14 Year 2012. There are some items related to the installation of sprinklers that did not meet the standards. The hydrants are not equipped with labels with instructions for use, and some hydrant boxes are empty and have not been reequipped. One of the factors lead to an empty fire hydrant box is the workforce have perceived that the presence of a fire station in the office complex is sufficient to tackle fires. Also, there are objects hindering the access to some hydrants in the building, so it may be difficult for officers to deploy a hose or open the hydrant box. The residual water pressure in the hydrants is 3 bars which inaccurate pressure setting on the water pump may have caused this low residual water pressure. This can reduce the strength of the water jets so that the hydrant cannot effectively reach and extinguish the fire. The fire extinguishers have been replaced, so they are all fully charged, ready to use, and stored in the proper place. They are multipurpose dry chemical extinguishers. The user-guide labels and inspection cards for the fire extinguishers are unavailable, which are considered sufficient. In this case, there are no references regarding the number or schedule of inspections or the conditions of the fire extinguishers. 


\subsection{Passive fire protection system}

The building frame is made of reinforced concrete and the exterior walls are made of brick and masonry. The floor is made of concrete covered by ceramic tile and tiles are used for the roof. The walls are fire-resistant but there are no fire doors and windows installed. The building uses the principle of compartmentalization and the compartments are formed by material that is resistant to fire. The interior walls and partitions are finished with plaster cement, paint, or gypsum board. The finishing surfaces of the halls are fixed with wallpaper and carpets as one of the floor finishing.

TABLE 1: The incompatibility of fire protection system in Depok government building.

No. Variable

Active Fire Protection System

\section{Fire Detectors}

1. The detector is not installed near the ventilation system.

2. The detector inspection is conducted twice a year.

3. The detector is not blocked.

\section{Status Remark}




\section{No. Variable}

1. Each rack or storage for $40 \mathrm{~mm}$ hoses is labeled with user guide that should be used only by trained personnel.

2. The $25.4 \mathrm{~mm}$ hoses are allowed to be used in buildings with minor hazard.

3. The connection between hose and hose station should not be blocked and installed not less than $0.9 \mathrm{~m}$ and not more than $1.5 \mathrm{~m}$ from the floor.

4. The Class I System (if available) is installed in the landing floor of the stairs and each exit route.

5. The standpipe system and hoses are installed in each exit stairs.

6. The minimum of residual pressure on the output of 2.5 -inch hose is 6.9 bars and on the 1.5 -inch hose is 4.5 bars.

\section{Status}

Incompatible

Remark

N/A This building uses $40 \mathrm{~mm}$ or 1.5 in hoses.

Incompatible

Some hydrants in the room (except corridors and lobby) are blocked by office tools, such as container, keyboard, and so on. The installation is appropriate.

N/A The building uses Class II System (1.5-m hose connection).

Incompatible

There is no standpipe system and hoses that installed in the exit stairs.

Incompatible The result of commissioning test in 2015 showed that the minimum pressure is only 3 bars.

\section{Fire Extinguisher}

1. The types and classification of fire extinguishers are appropriate with material that exist in the place.
Incompatible

The building only used multipurpose dry chemical fire extinguishers. The fire extinguisher of carbon monoxide type is not used.

2. The fire extinguisher that is more than $18 \mathrm{~kg}$ is installed not more that $1 \mathrm{~m}$ from the floor.

3. The fire extinguisher is equipped with manufacturing label, operating label, fire extinguisher type label, checking label, or inventory label.

4. The storage cabinet of fire extinguisher should not be locked, unless prone to be misused.
N/A There is no fire extinguisher more than $18 \mathrm{~kg}$.

Incompatible The fire extinguisher is not equipped with checking label/card.

N/A The fire extinguisher does not use storage cabinet.

\section{Passive Fire Protection System}

\section{Fire Doors and Windows}

1. There are fire doors and windows with specific level of fire-retardant.

2. The doors can self-closing.

\section{Incompatible}

Incompatible doors.

The building does not use fire doors, but in general, the regular doors that used are wood doors with passkey. The doors cannot close themselves. Several rooms use self-closing doors of wood and glass. The main entrance is an automatic glass door.

3. The fire doors that protect the exit Incompatible route should be able to self-closing.

Not all doors are self-closing. Only the doors to the emergency stairs are self-closing and made of fireproof material (iron). 


\begin{tabular}{|c|c|c|c|}
\hline No. & Variable & Status & Remark \\
\hline 4. & $\begin{array}{l}\text { The fire windows are fixed or } \\
\text { automatic closing. }\end{array}$ & N/A & No fire windows in the building. \\
\hline 5. & $\begin{array}{l}\text { No cracks or holes in the door } \\
\text { surface. }\end{array}$ & N/A & No fire doors in the building. \\
\hline 6. & $\begin{array}{l}\text { No damage to the hinges, doors, } \\
\text { and door frames. }\end{array}$ & N/A & No fire doors in the building. \\
\hline 7. & $\begin{array}{l}\text { The opening area of the door should } \\
\text { be free from objects that may block } \\
\text { the access and the operation of the } \\
\text { door. }\end{array}$ & N/A & No fire doors in the building. \\
\hline \multicolumn{4}{|c|}{ Compartmentalization } \\
\hline 1. & $\begin{array}{l}\text { Compartment is equipped with fire } \\
\text { retardant doors. }\end{array}$ & Incompatible & $\begin{array}{l}\text { The building does not use fire } \\
\text { retardant doors, except the doors in } \\
\text { the emergency stairs. }\end{array}$ \\
\hline 2. & The door used is self-closing door. & Incompatible & $\begin{array}{l}\text { Only a few rooms that use } \\
\text { self-closing doors. }\end{array}$ \\
\hline \multicolumn{4}{|c|}{ Interior Finish } \\
\hline 1. & $\begin{array}{l}\text { The textile material that installed on } \\
\text { the wall or ceiling should be } \\
\text { protected by sprinkler. }\end{array}$ & N/A & $\begin{array}{l}\text { No walls or ceiling are installed with } \\
\text { textile materials. However, the floor } \\
\text { of the hall in the } 5^{\text {th }} \text { floor is covered } \\
\text { with carpet and protected by } \\
\text { sprinkler. }\end{array}$ \\
\hline 2. & $\begin{array}{l}\text { The vinyl material that installed on } \\
\text { the wall or ceiling should be } \\
\text { protected by sprinkler. }\end{array}$ & N/A & No coating of vinyl material. \\
\hline
\end{tabular}

\section{Discussion}

This study has found that the Management of Government Building tried to maintain the active and passive fire protection systems in accordance with the standards and regulations, such as making smoke and heat detectors available on every floor of the building, installing a fire alarm that can determine the origin of the fire, and installing the required sprinklers in accordance with NFPA 13, so that the construction would be in compliance if a fire occurred [9]. Fire protection systems must be provided in order to detect and extinguish fires, provide warnings, and ensure a safe exit for occupants $[17,18]$. There are still some areas, for example, working spaces in $2^{\text {nd }}$ floor both the active and passive fire protection systems that do not meet the standards.

\subsection{Active fire protection systems}




\subsubsection{Heat and smoke detectors}

For active fire protection system, our study has shown that some detectors were installed close to (approximately $40-50 \mathrm{~cm}$ from) an air conditioning vent. This is not in accordance with the NFPA 72 standards because the placement may affect the ability of the detector to detect heat or smoke nearby [11]. Air conditioning and ventilation systems with a high airflow rate can negatively affect the response of the detector [19]. Heat detectors respond when the ambient temperature reaches a fixed point, commonly $58^{\circ} \mathrm{C}[20]$.

The existing study has reported that the detectors in the Government Building were recorded, have been tested and inspected at least once a year. The frequency of testing is in accordance with NFPA 72 and Regulation of the Ministry of Public Works No. 26/PRT/M/2008, but the frequency of inspections does not meet the applicable regulations and standards. Periodic testing and maintenance is required for fire detection systems and devices to function properly. In addition, detectors should be cleaned regularly to remove dust or dirt that could cause system errors in a fire [19].

\subsubsection{Fire alarms}

Also, our study has found that alarms with buzzer and strobe light notifications were installed $1.4 \mathrm{~m}$ above the floor, but this placement does not meet the requirements of NFPA 72, which calls for a placement of not less than $2.29 \mathrm{~m}$ above the floor [11]. Furthermore, the main fire alarm control (the 'fault' LED light) was switched on all the time. This condition may result with damage to the detector or the alarm circuit or wiring [21]. The detector will not able to detect heat or smoke (if the fault sign is caused by a broken detector), or there will be no signal between the detector and the alarm system (if the fault sign is caused by a bad circuit), when a fire starting in the area. The frequency of alarm testing is in accordance with NFPA 72 and Regulation of the Ministry of Public Works No. 26/PRT/M/2008, but the frequency of inspections is not sufficient. Therefore, in the event of fire the alarm may not work and allowing fire to spread unnoticed and endangering the building's occupants.

\subsubsection{Automatic sprinkler}

This study has shown that the sprinkler pipe installation fulfills the requirements of NFPA 139, and the water used comes from Depok Local Water Company, therefore 
the water in the sprinklers is clean, not muddy or sandy. However, the installation of sprinklers is 4.7-meter distance between the sprinklers and there is a room partition built, these set up are not meeting the applicable standards. According to the provisions of NFPA 13 require a maximum distance of 4.6 -meter between the sprinklers. The excess distance will lead to an uneven distribution of the water jets, which will reduce the sprinkler's effectiveness in preventing or extinguishing any fire propagation [6]. The room partition can affect the performance of the sprinkler by obstructing the water jets. It was built to accommodate the activities of the office without paying attention to the process of ceiling sprinkler installation.

\subsubsection{Standpipe system}

The current study has highlighted some hydrant boxes are empty and have not been reequipped, thus this will complicate the efforts to extinguish a fire when a hydrant is needed to do so. Furthermore, the pillar hydrants or hydrants in front of the building are also not equipped with a hose box, nozzle, hose, and hydrant key. The hydrants are not equipped with labels with instructions. According to the provisions of NFPA 14, the building's hydrant should be complete with a nozzle, hose, shelf, or storage area. The hydrant should be equipped with instruction and signage. The signage and label should say 'should only be used by trained personnel', as required by NFPA 14 [10].

In this study, the results of the commissioning test indicated that the residual water pressure in the hydrants was only 3 bars. The hydrants are supplied by water coming from Depok Local Water Company and two tanks of 10,000 L each. If the capacity of the water tanks $(20,000 \mathrm{~L})$ is divided by the flow rate of the pump $(63 \mathrm{~L} / \mathrm{s})$, the result shows that the hydrants can release water for only 5 minutes before being depleted. The hydrants will then depend on the availability of water from taps and fire engines. According to the provisions of Regulation of the Ministry of Public Works No. 26/PRT/M/2008, the water pressure on the rest of the hose connection should be 6.9 bars in the 2.5 -in hose and 4.5 bars in the 1.5 -in connection hose [15].

\subsubsection{Fire extinguishers}

Our study has highlighted that the fire extinguishers are in good conditions and are checked as well as replaced only once a year. They only have a user guide affixed to the tube of the fire extinguisher and are not equipped with inspection cards. The conditions 
of the fire extinguishers are in accordance with the provisions of NFPA $10^{8}$ and Regulation of the Mayor of Depok No. 14 Year 2012 [16]. However, these are multipurpose dry chemical extinguishers and the type suitable for electronic equipment is not available in other parts of the building. For office building, the greatest potential for a major fire is caused by defected electronic equipment, which requires Class $C$ carbon dioxide fire extinguishers [8]. A lack of inspections means that the conditions of the building's fire extinguishers may not be known. The NFPA 10 requires that fire extinguishers have the instructions for use on the labels. In reference to the Regulation of the Ministry of Public Works No. 26/PRT/M/2008 requires inspections of the fire extinguishers every 30 days, complete with an archive or inspection record [15]. It is important to conduct regular inspections and maintenance of the fire protection systems [26].

\subsection{Passive fire protection systems}

\subsubsection{Building construction}

Our study's finding has shown that the building is made from appropriate materials including: reinforced concrete structure; exterior as well as interior walls are made of brick and masonry; ceiling is made of gypsum; floor is made of concrete with ceramic tiles and tiles roofing. Reinforced concrete is known to be able to withstand collapse and to perform well when exposed to fire, although it will eventually be weakened by fire, but the structural stability will remain for long periods of time [6]. The exterior walls that made of brick and masonry may provide protection from fire and serving to inhibit or prevent any hot or burning debris from spreading throughout the building. Masonry generally holds up well against rising temperatures. The bricks can withstand high temperatures without suffering severe damage $[6,21]$. The interior walls are made of the same material of exterior walls, so their fire resistance is approximately equal to that of the exterior walls. The floor of the building is made of concrete covered by ceramic tile. The level of fire resistance of the flooring is estimated by the NFPA to be 2 hours. The ceiling, made with gypsum, has a fire resistance of about 1 hour [6]. The roof of the building use tiles that are classified by NFPA 256 as a Class A roof covering, which is noncombustible and resistant to large fire exposure [22].

\subsubsection{Fire-retardant assembly}

Another main finding of our study is the walls are fire-resistant but there are no fire doors and windows installed. The fire-resistant and fire barrier walls are in line with 
provisions of NFPA 101, NFPA 221, and NFPA 5000, such as all the walls being well maintained (no cracks or holes) and the total width of the wall openings on a floor not exceeding 25 percent of the length of the wall. However, the doors and windows that are used to protect the openings in the walls are not the fire-retardant that are required by the NFPA $[12,14,24]$.

\subsubsection{Fire doors and windows}

As mentioned earlier, the building has ordinary wooden doors and glass doors (with passkeys, self-closing doors, and automatic doors), while the windows are glass with wooden frames. These conditions are not meeting the requirements of NFPA 101, NFPA 80 , and NFPA $5000[12,14,25]$. The wood may survive a fire, but no matter what shape, size, or treatment, all the wood will eventually burn and lose its structural durability $[6,21]$. Ordinary glass has a very low resistance to fire; the glass will break easily due to the temperature difference between the air and the glass surface [6]. If the glass in the window of a room ruptures, it can cause the fire to spread to another room and grow larger.

\subsubsection{Compartmentalization}

We also found that the building uses the principles of compartmentalization with interior walls are made of cement and brick, but fireproof doors do not protect the compartments. It's compartmentalization aspect is in accordance with the provisions of NFPA 101 and NFPA 5000, however the requirement is the compartment to be made from material that is resistant to fire. The interior walls are made of cement and brick and are fire resistant for 2 hours or more. As stated earlier, the doors are wooden or ordinary glass doors that are able to self-close or require a passkey (that automatically locked when doors are closed). These types of doors can close and contain a fire for a short time until the occupants manage to escape from the building. One of the main causes of failure for a compartment in limiting the spread of fire is a door that cannot be closed [6].

\subsubsection{Interior finish}

Finally, our study has shown that the finished interior walls and partitions are finished with plaster cement, paint, or gypsum board. These materials fulfill the requirements 
of NFPA 101 and NFPA 5000. The plaster cement has a flame-spread index of o, gypsum board has a flame-spread index of 10-15, and ceramics have a flame-spread index of o [27]. In addition, the building also uses the wallpaper as a finishing surface in the halls and carpets as one of the floor finishing. Wallpaper has been installed on the noncombustible walls, in accordance with the provisions of NFPA 101, which allows the installation of an interior finish with a thickness of less than $6.4 \mathrm{~mm}$ over a surface of noncombustible material [12]. Carpets are generally flammable, but the rooms with carpets are protected by sprinklers, thus fulfilling the provisions of NFPA 101 and NFPA 5000 , which allow the installation of an interior finish if the automatic sprinkler system is installed in the room $[12,24]$.

\subsubsection{Limitations}

The main limitation of the study is the data collection method used (direct observation and self-reported interviews with the relevant stakeholders such as building technicians, general section and fire inspectors) may be subjected to recall and reporting biases. Other limitations are lack of secondary data to verify the observations, and also engineering calculations were not performed.

\subsubsection{Recommendations}

There is lack of awareness, knowledge and commitment to fire safety among the workforce, and has affected effective implementation of fire protection systems in the building. There are gaps between standard/regulation and the condition of fire protection systems in the building. The main factor contributing to the gaps is lack of knowledge about the essence of the building management system and standard fire protection that resulted in false perception of adequate fire protection systems and poor testing practice of the fire protection systems for office buildings. The current implementation seems to be sufficient only for the minimum compliance and standard. For safe system of work, the entire system of active and passive fire protection need to be tested simultaneously and this may indicate that the system would work well in case of an emergency. For best practice, there is a need for regular inspections and maintenance of the fire protection systems in all buildings including offices. 


\section{Conclusion}

This study has found that there are minimal active and passive fire protection systems in office buildings, and few components are not adequately practiced in accordance with standards and regulations (NFPA, Regulation of the Minister of Public Works No. 26/PRT/M/2008, Regulation of the Mayor of Depok No. 14 Year 2012). It is important to identify main issues in the fire protections systems in the building (such as damage to the alarm circuits, the lack of complete hydrants) and the gaps in implementation of the existing standard/regulations. The failure to control fire risks can result in heavy loss to the organization in terms of injury to the workforce, financial loss due to property and equipment damage and legal consequences.

\section{References}

[1] National Fire Protection Association (NFPA). Fires in the US 2016. United States. Retrieved from http://www.nfpa.org/research/reports-and-statistics/fires-inthe-us (accessed on 25 February 2016).

[2] International Association of Fire and Rescue Services. World Fire Statistics 2015. Swedia. Retrieved from http://www.ctif.org/sites/default/files/ ctif_report20_world_fire_statistics_2015.pdf (accessed on 17 February 2016).

[3] Dinas Penanggulangan Kebakaran dan Penyelamatan Provinsi DKI Jakarta. Dato Kebakaran Tahun 2015. Jakarta. Retrieved from http://www.jakartafire.net/ statistik/index.php?tahunkat=2015 (accessed on 9 February 2016).

[4] Dinas Pemadam Kebakaran Kota Depok. Profil Dinas Pemadam Kebakaran Kota Depok. Depok. Retrieved from http://damkar.depok.go.id/data-kebakaran (accessed on 9 February 2016).

[5] Fire Safety Advice Centre. Offices and Shops. United Kingdom. Retrieved from http:// www.firesafe.org.uk/fire-safety-in-offices-and-shops/ (accessed on 26 February 2016).

[6] National Fire Protection Association. (2008). Fire Protection Handbook (12th edition). United States: National Fire Protection Association.

[7] National Fire Protection Association. (2012). NFPA 1: Fire Code. United States: National Fire Protection Association.

[8] National Fire Protection Association. (2013). NFPA 10: Standard for Portable Fire Extinguisher. United States: National Fire Protection Association. 
[9] National Fire Protection Association. (2013). NFPA 13: Standard for The Installation of Sprinkler System. United States: National Fire Protection Association.

[10] National Fire Protection Association. (2013). NFPA 14: Standard for The Installation of Standpipe and Hose System. United States: National Fire Protection Association.

[11] National Fire Protection Association. (2013). NFPA 72: National Fire Alarm and Signaling Code. United States: National Fire Protection Association.

[12] National Fire Protection Association. (2012). NFPA 101: Life Safety Code. United States: National Fire Protection Association.

[13] National Fire Protection Association. (2015). NFPA 220: Standard on Types of Building Construction. United States: National Fire Protection Association.

[14] National Fire Protection Association. (2009). NFPA 5000: Building Construction and Safety Code. United States: National Fire Protection Association.

[15] Regulation of the Minister of Public Works No. 26/PRT/M/2008 on Technical Requirements for Fire Protection System in Buildings and the Environment.

[16] Regulation of the Mayor of Depok No. 14 Year 2012 on Technical Requirements of Fire Protection System in Buildings and the Environment.

[17] Chow, W. K. and Lui, G. C. H.(2001). Evaluating building fire safety for business occupancies. International Journal on Engineering Performance-Based Fire Codes, vol. 3, no. 1, pp. 16-24.

[18] Ong, W. C. and Suleiman, M. Z. (2014). Problems in implementation of fire safety management in Malaysia government hospital. Advances in Environmental Biology Journal, vol. 9, no. 4 .

[19] Tse, C. M. (2004). Evaluation of the performance of fire detection system in an institutional building. International Journal on Engineering Performance-Based Fire Codes, vol. 6, no. 4, pp. 333-43.

[20] Tiwari, S., Phadke, B. N., Patel P. (2013). Design of fire alarm and detection system for hospital. International Journal of Engineering Research \& Technology, vol. 2, no. 10.

[21] Ferguson, L. H. and Janicak, C. A. (2005). Fundamentals of Fire Protection for the Safety Professional. United States: Government Institutes.

[22] National Fire Protection Association. (2003). NFPA 256: Standard Methods of Fire Tests of Roof Coverings. United States: National Fire Protection Association.

[23] International Code Council. (2012). North Carolina Building Code (2nd printing). United States: International Code Council, Inc. 
[24] National Fire Protection Association. (2015). NFPA 221: Standard for High Challenge Fire Walls, Fire Walls, and Fire Barrier Walls. United States: National Fire Protection Association.

[25] National Fire Protection Association. (2016). NFPA 80: Standard for Fire Doors and Other Opening Protectives. United States: National Fire Protection Association.

[26] Kironji, M. (2015). Evaluation of fire protection systems in commercial highrise buildings for fire safety optimization: A case of central business district. International Journal of Scientific and Research Publications, vol. 5.

[27] Louisiana Office of State Fire Marshal. (n.d.). Flame-spread Ratings. United States. Retrieved from http://sfm.dps.louisiana.gov/doc_flamespread.html (accessed on 20 April 2016).

[28] Murali, L. G. and Vijayalakshmi, M. M. (2014). Fire accidents in buildings - Case studies. International Journal of Engineering Trends and Technology, vol. 11, no. 4. 